\title{
Efficacy of Some Pesticide Alternatives on the Desert Locust Schistocerca gregaria (Forskal) Under Laboratory and Field Conditions
}

\author{
Soliman M.M.M. ${ }^{1}$, K.M. Mohanna ${ }^{2}$, T.A. Abdel-Fattah ${ }^{3}$, O.R.M. Moustafa ${ }^{4 *}$ \\ ${ }^{1}$ Plant Protection Department, Faculty of Environmental Agriculture, Technology and Food \\ Sciences, Beni-Suef University, Egypt. \\ ${ }^{2}$ Plant Protection Department, Faculty of Agriculture, South Valley University, Qena, Egypt. \\ ${ }^{3}$ Head researcher of plant protection research institute (PPRI), Locust and Grasshoppers \\ Department. (Agriculture Research Center) \\ ${ }^{4}$ PhD Candidate, (Plant Protection Department, Faculty of Agriculture, South Valley University), \\ General Department for Locust and Agro-aviation's Affairs
}

\begin{abstract}
The efficacy of chlorantraniliprole (Coragen $®)$, spinosad (Tracer $®)$ and fipronil $\left(\right.$ Coatch $\left.{ }^{\circledR}\right)$ was tested under laboratory conditions against the $5^{\text {th }}$ nymphal instars and adult stages of the Desert Locust Schistocerca gregaria (Forskal), using various concentrations of the mentioned compounds by feeding technique. Fipronil showed the highest efficacy on both stages, followed by spinosad while chlorantraniliprole caused lower mortality. The effect of sublethal concentrations $\left(\mathrm{LC}_{30}\right)$ of the mentioned insecticides on the life span and fledging rate of $5^{\text {th }}$ nymphal instar was investigated. $5^{\text {th }}$ nymphal instar took $12.6,15.6$ and 11.6 days to fledge in the treatments of chlorantraniliprole, spinosad and fipronil respectively, which are significantly longer than the duration spent by the untreated $5^{\text {th }}$ nymphal instar to fledge $(8.8$ days). Successful fledging rates of $5^{\text {th }}$ nymphal instars were $42.6 \%, 75 \%$ and $25 \%$ for the treatments of chlorantraniliprole, spinosad and fipronil respectively, which are significantly lower than that of the untreated hoppers (100\% fledged successfully). Deformation occurred in $30 \%$ of the $5^{\text {th }}$ nymphal instars treated by $\mathrm{LC}_{30}$ of fipronil and spinosad. Field tests, executed in Abu_Ramad, southeast Egypt, showed that chlorantraniliprole at dose rate of $24 \mathrm{~g}$. a. i. /ha, spinosad at dose rate of 15.12 g. a. i. /ha, and fipronil at dose rate of 0.4 g. a. i. /ha, resulted in 98, 99 and 100\% mortality to mixed populations of hoppers and adults of $S$. gregaria within two days of field application.
\end{abstract}

Key words: Insects, Schistocerca gregaria, insecticide alternatives, fledging, field conditions

\section{INTRODUCTION}

The Desert Locust, Schistocerca gregaria (Forskal) is considered the most economically important insect pest in Egypt as well as in other African and Asian countries. The insects cause great damages to crops and pastures when they increase in numbers and form hopper bands or swarms.

\footnotetext{
*Corresponding author: Osama R.M. Moustafa,

Email: osamarabie32@gmail.com

Received: May 1, 2019;

Accepted: May 9, 2019;

Published: May 13, 2019.
}

The chemical control of locusts using the organophosporous pesticides and synthetic pyrethroides is still the main tool to control locusts, while organochlorines were banned due to their persistence and severe effects on the environment (Lecoq, 2001). The widespread use of the synthetic pesticides has considerable negatives such as handling hazards, the development of insect resistance to insecticides, increased costs, concerns about insecticide residues, and great threats to both human and environmental health (Garriga and Caballero, 2011), which occurs due to pollution by the chemical pesticides such as toxicity to non-target organisms 
(Tingle, 1996) and to humans (Pretty, 1996). This study aims to find safer alternatives, for human and environment, than the conventional insecticides. The study suggests new alternative compounds from various groups of pesticides to control the desert locust including chlorantraniliprole from the anthranilic diamides group, spinosad as a biological agent and fipronil from phenylpyrazoles.

\section{Materials and methods}

\section{Test insects and bioassay}

The insects of the desert locust $S$. gregaria were reared under laboratory conditions. They were obtained from the stock culture maintained for several generations at the Locust Research Section, Plant Protection Research Institute (PPRI), ARC, Dokki, Giza. The insects were reared according to Robert et al., (2002) in wooden framed cages measuring $(55 \times 55 \times 60 \mathrm{~cm})$ and the insects were fed on branches of clovers, Trifolium alexandrinum. The locusts' cages were kept at $30 \pm 3{ }^{\circ} \mathrm{C}$ and $20-25 \%$ Relative Humidity.

Feeding technique was used in the laboratory to study the effect of different concentrations of chlorantraniliprole 20\% SC (Coragen ${ }^{\circledR}$ ), spinosad 24\% SC (Tracer®), and fipronil $20 \%$ SC (Coach $囚)$ on the mortality rates of one day old $5^{\text {th }}$ nymphal instar and seven days old adults of $S$. gregaria. The hoppers and adults were treated separately, and subdivided into groups of 50 hoppers or adults for each treatment, with five replicates of ten nymphs or adults were assigned for each treatment. The hoppers and adults were starved for 24 hours and were fed on clover leaves dipped for 10 seconds in: 60, 240, 480 and $600 \mathrm{ppm}$ of chlorantraniliprole, 30, 60, 120 and $180 \mathrm{ppm}$ of spinosad and 0.1, 0.5, 1 and $2 \mathrm{ppm}$ of fipronil. The leaves were air dried under room temperature for one hour before presenting to the nymphs and adults, and water dipped leaves was presented to the untreated hoppers and adults. The treated leaves were replaced with non-treated ones after $24 \mathrm{hr}$. the mortality was recorded after
1, 2 and 3 days of treatment. $\mathrm{LC}_{30}, \mathrm{LC}_{50}$ and $\mathrm{LC}_{90}$ were calculated using (Ldp line) software according to the method of Finney (1971).

\section{Field trial}

Extensive field surveys were carried out in southeast Egypt during the winter breeding seasons of 2017/2018 and 2018/2019 (the winter breeding season extends from October to March every year) in order to find a suitable site for the field application. Surveys were conducted according to the technique explained in the Food and Agriculture Organization desert locust guidelines by Cressman (2001). No infestations occurred during the first breeding season because only light rains fell in that season. Whereas; heavy rains fell in the area at the beginning of the second season (2018/2019) resulted in providing favourable ecological conditions for desert locust breeding. Vegetation grew and soil moisture became suitable for egg laying by desert locust females. Isolated mature solitary adults were seen at the beginning of the season and copulating and laying occurred in various sites of $\mathrm{Abu}$ Ramad and Shalatyn (See the maps in figure 1). Hatching started at the end of December 2018, and worthy numbers of hoppers resulted from this breeding. The number of hoppers increased in January 2019 and reached 5 hoppers $/ \mathrm{m}^{2}$ (with $3^{\text {rd }}, 4^{\text {th }}$ and $5^{\text {th }}$ instar nymphs), in addition to immature adults, at few sites in the area of Jabal Elba, while lower numbers were detected in the other survey areas.

The experimental site was selected to conduct the field test located in Abu_Ramad at $\left(22^{\circ} 15^{\prime}\right.$ North $/ 36^{\circ} 23^{\prime}$ East $)$. Hoppers of medium to late instars and newly emerged adults were found at the site of the experiment. Four plots of 50 by 50 meters each were selected and demarcated by flags. In each plot, 4 nets of $1 \mathrm{~m}^{2}$ each were fixed on the vegetation (they represent the replicates of each treatment) and a number of 30 hoppers and adults was collected from the 
treatment site and were put under each of these nets. The nets in the plot allowed recording the mortality and prevented insects from escaping after spraying. The plots were aligned in parallel direction to the prevailing wind, in order to inhibit pollution of spray drift from one plot to the other during spraying. Control plot was put upwind in relation to the others and sprayed with water only. Spraying was executed in the early morning when conditions were suitable for spraying (wind speed: 2-3 $\mathrm{m} / \mathrm{second}$, measured using anemometer, temperature: $18^{\circ} \mathrm{C}$. and relative humidity: $43 \%$ ). Spraying was executed using Knapsack mistblower sprayer with flow scale graded from 1 to 5; the scale no 2 was selected and calibrated. The flow rate was $1200 \mathrm{ml} / \mathrm{min}$; s spraying height was $0.5 \mathrm{~m}$ above vegetation and walking speed of the operator was $40 \mathrm{~m} / \mathrm{min}$. $=2.4 \mathrm{~km} / \mathrm{hr}$. with swath width of $5 \mathrm{~m}$. Mortality counts were recorded after different periods of treatment, i.e., 3, 6, 12, 24 and 48 hours of application considering the treated insects under the fixed nets in each plot. The green circles on the left map represent the sites with green vegetation and the yellow circles represent the sites with dry vegetation. Whereas; the blue "L" symbols on the right map represent the sites of mature adults of $S$. gregaria which can copulate and lay eggs.

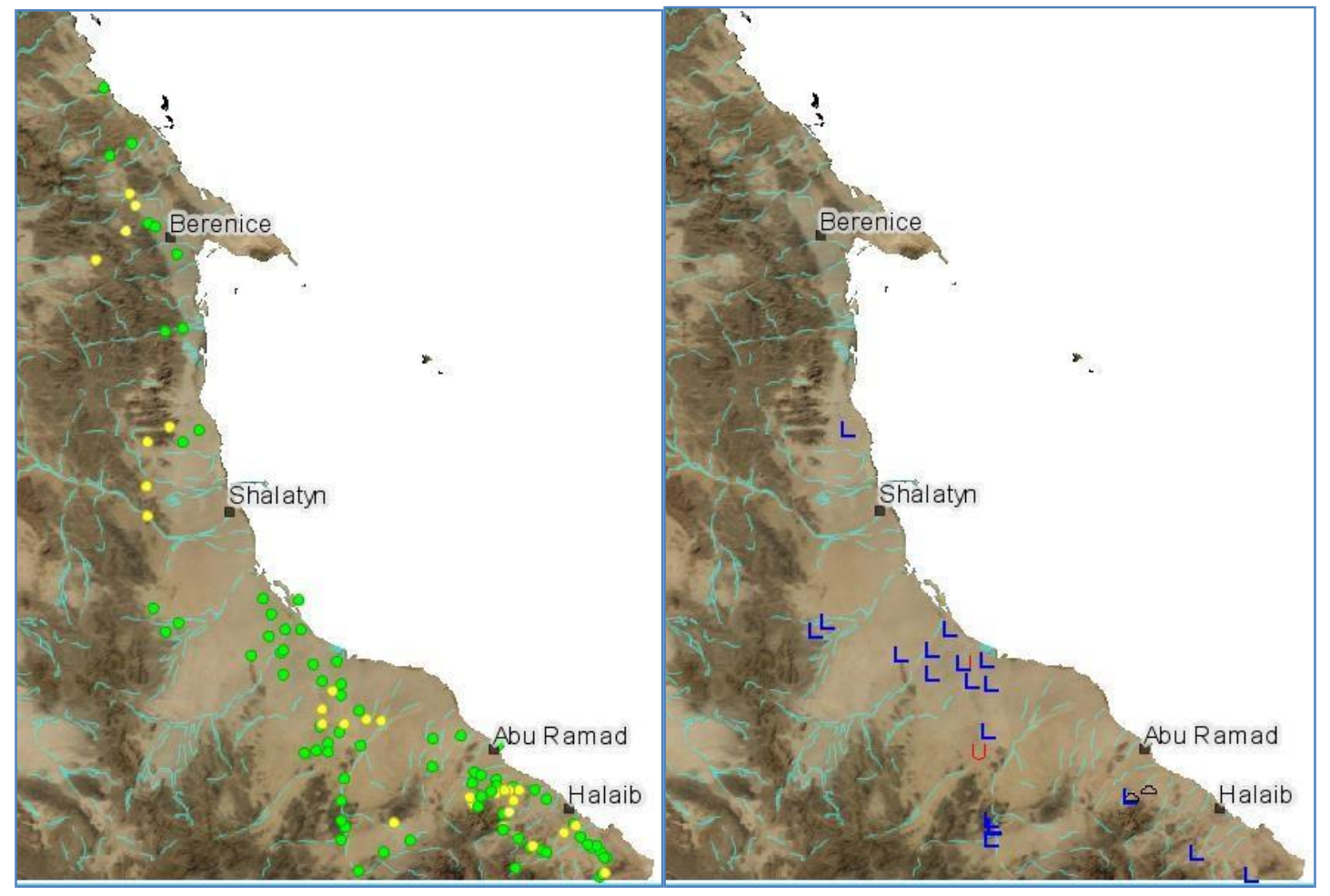

Figure 1: Maps showing vegetation state and desert locust infestations in December 2018 and January 2019 in southeast Egypt 


\section{Results and discussions}

The mortality percentages of the $5^{\text {th }}$ nymphal instars and adults of S. gregaria under laboratory conditions

The corrected mortality percentages due to the treatments by chlorantraniliprole, spinosad and fipronil were calculated by using Abott's formula (1925) as follows: Corrected $\%$ mortality $=$

$(1-\underline{\mathrm{n} \text { in } \mathrm{T} \text { after treatment }}) \times 100$

$\mathrm{n}$ in Co after treatment

Where $\mathrm{n}=$ insect population, $\mathrm{T}=$ treated and Co $=$ control.

Data in table 1 indicates the corrected mortality rates of one-day old $5^{\text {th }}$ nymphal instar after 1, 2 and 3 days of treatment with various concentrations of clorantraniliprole, spinosad and fipronil. After treatment with $60, \quad 240, \quad 480$ and $600 \mathrm{ppm}$ of clorantraniliprole, the mortality percentages were $(20 \%$ and $43.3 \%),(46.7 \%$ and $70 \%)$, $(60 \%$ and $83.3 \%)$ and $(70 \%$ and $96.7 \%)$ for the $5^{\text {th }}$ nymphal instars and adults of $S$. gregaria, respectively. The finding agrees with those found by Cao et al., (2017) in a laboratory trial which indicated that chlorantraniliprole (Prevathon ${ }^{\circledR}$ ) was effective against $3^{\text {rd }}$ instar hoppers of the oriental migratory locust, Locusta migratoria $L$.

In addition; the corrected mortality rates after 3 days of treatment with $30,60,120$ and 180 ppm of spinosad were $(34.48 \%$ and $62.1 \%$,), (55.2\% and $79.3 \%),(86.2 \%$ and $100 \%)$ and $(100 \%$ and $100 \%)$ for the $5^{\text {th }}$ nymphal instar and adults of $S$. gregaria, respectively. The result agrees with the finding by Kamel (2018) who found that spinosad (Tracer®) caused $100 \%$ mortality to the $4^{\text {th }}$ instar hoppers of $S$. gregaria after 48 hours of treatment using feeding technique. Also, Said (2014) obtained similar results under laboratory conditions as he found that spinosad caused similar levels of mortality when $5^{\text {th }}$ instar nymphs of S. gregaria were exposed to spinosad dipped clover leaves.

Moreover; the corrected mortality rates after 3 days of treatment with $0.1,0.5,1$ and 2 ppm of fipronil were $(51.9 \%$ and $55.6 \%)$, (85.2\% and $88.9 \%),(96.30 \%$ and $100 \%)$ and (100 and $100 \%)$ for the $5^{\text {th }}$ nymphal instars and adults of $S$. gregaria, respectively. This finding is in line with that found by Ibrahim (2018) who found that fipronil (Coach®), under laboratory conditions, achieved $100 \%$ mortality after $24 \mathrm{hr}$. to the $4^{\text {th }}$ nymphal instar of $S$. gregaria using a concentration of $0.5 \mathrm{ppm}$, and $55.6 \%$ mortality occurred to the same instar by using a concentration of 0.12 ppm after 48 hours of treatment.

The data in table 2 shows the values of $\mathrm{LC}_{30}$, $\mathrm{LC}_{50}$ and $\mathrm{LC}_{90}$ for $S$. gregaria after 3 days of treatment with above mentioned concentrations for each of the selected pesticides. The probit regression lines for the used concentrations of the tested insecticides against hoppers and adults are demonstrated graphically in figure 2 .

The mentioned results indicate that adults of $S$. gregaria are more sensitive to all tested compounds than $5^{\text {th }}$ nymphal instars. This could be due to the higher food consumption by the immature adults, and also can be due to the larger exposed body surface for adults when compared to hoppers, which allowed adults to be in better contact chances with the insecticide dipped leaves.

Effect of $L_{30}$ of chlorantraniliprole, spinosad and fipronil on some biological aspects of $S$. gregaria

Data in table 3 indicates the effects of sub lethal concentrations $\left(\mathrm{LC}_{30}\right)$ of chlorantraniliprole, spinosad and fipronil on life span, hopper deformation and adult fledging of $5^{\text {th }}$ nymphal instars of $S$. gregaria. Sub lethal concentrations represent the low doses of the insecticide which usually occur in the field after few days of applications. $5^{\text {th }}$ nymphal instar spent an average of 12.6, 15.6 and 11.6 days to moult into adults for the treatments of chlorantraniliprole, spinosad and fipronil respectively. These periods are significantly longer than the duration of 8.8 days taken by the untreated $5^{\text {th }}$ nymphal instars to fledge. 
Deformation followed by death occurred in $30 \%$ of the hoppers treated with fipronil and spinosad (figure 3). Rates of hoppers that successfully moulted into adults were $42.6 \%$, $75 \%$ and $25 \%$ for the treatments of chlorantraniliprole, spinosad and fipronil respectively, while $100 \%$ of the untreated hoppers fledged successfully. El_Gammal et al. (2004) found that cycloheximide (RNA and protein synthesis inhibitor) caused 72.5 , 70 and $60 \%$ permanent $4^{\text {th }}$ instar nymphs of $S$. gregaria after treatment with doses of 480 , 200 and $100 \mu \mathrm{g} /$ insect for each dose respectively.

Table 1. Corrected mortality percentages of $5^{\text {th }}$ nymphal instars and adults of S. gregaria using different concentrations of clorantraniliprole, spinosad and fipronil

\begin{tabular}{cccccccc}
\hline \multirow{2}{*}{ Treats. } & $\begin{array}{c}\text { Days } \\
\text { Conc. }\end{array}$ & \multicolumn{2}{c}{1 day } & \multicolumn{2}{c}{ 2 days } & \multicolumn{2}{c}{ 3 days } \\
& (ppm) & nymphs & adults & nymphs & adults & nymphs & adults \\
\hline & 60 & 10 & 20 & 16.67 & 30 & 20 & 43.3 \\
chlorantr- & 240 & 23.3 & 33.33 & 33.33 & 56.7 & 46.7 & 70 \\
aniliprole & 480 & 40 & 43.33 & 46.33 & 66.7 & 60 & 83.3 \\
& 600 & 46.7 & 66.67 & 53.33 & 91 & 07 & 96.7 \\
& & & & & & & \\
& 30 & 13.3 & 20 & 22.22 & 48.3 & 34.48 & 62.1 \\
& 60 & 23.3 & 43.33 & 50.19 & 69 & 55.17 & 79.3 \\
& 120 & 43.3 & 66.67 & 68.9 & 100 & 86.21 & --- \\
& 180 & 67.7 & 100 & 83.63 & --- & 100 & -- \\
& & & & & & & \\
& 0.1 & 20 & 36.67 & 29.6 & 40.7 & 51.9 & 55.6 \\
& 0.5 & 53.67 & 63.33 & 77.8 & 78.2 & 85.2 & 88.9 \\
\hline \multirow{2}{*}{ fiproninosad } & 1 & 66.67 & 90 & 88.9 & 99.6 & 96.30 & 100 \\
& 2 & 93.33 & 100 & 96.3 & --- & 100 & --- \\
\hline
\end{tabular}

Table 2. $\mathrm{LC}_{30}, \mathrm{LC}_{50}$ and $\mathrm{LC}_{90}$ values calculated after 3 days of treatments

\begin{tabular}{|c|c|c|c|c|c|c|c|c|c|}
\hline \multirow{2}{*}{ Locust } & \multicolumn{3}{|c|}{ chlorantraniliprole } & \multicolumn{3}{|c|}{ spinosad } & \multicolumn{3}{|c|}{ fpronil } \\
\hline & $\mathbf{L C}_{\mathbf{3 0}}$ & $\mathbf{L C}_{50}$ & $\mathbf{L C}_{90}$ & $\mathbf{L C}_{\mathbf{3 0}}$ & $\mathbf{L C}_{50}$ & $\mathbf{L C}_{90}$ & $\mathbf{L C}_{\mathbf{3 0}}$ & $\mathbf{L C}_{\mathbf{5 0}}$ & $\mathrm{LC}_{90}$ \\
\hline $\begin{array}{l}5^{\text {th }} \text { nymphal } \\
\text { instar }\end{array}$ & 107.8 & 271 & 2610 & 30.7 & 46.2 & 125.7 & 0.05 & 0.1 & 0.62 \\
\hline Adults & 39 & 85.7 & 587 & 17.4 & 26 & 68.6 & 0.048 & 0.09 & 0.40 \\
\hline
\end{tabular}




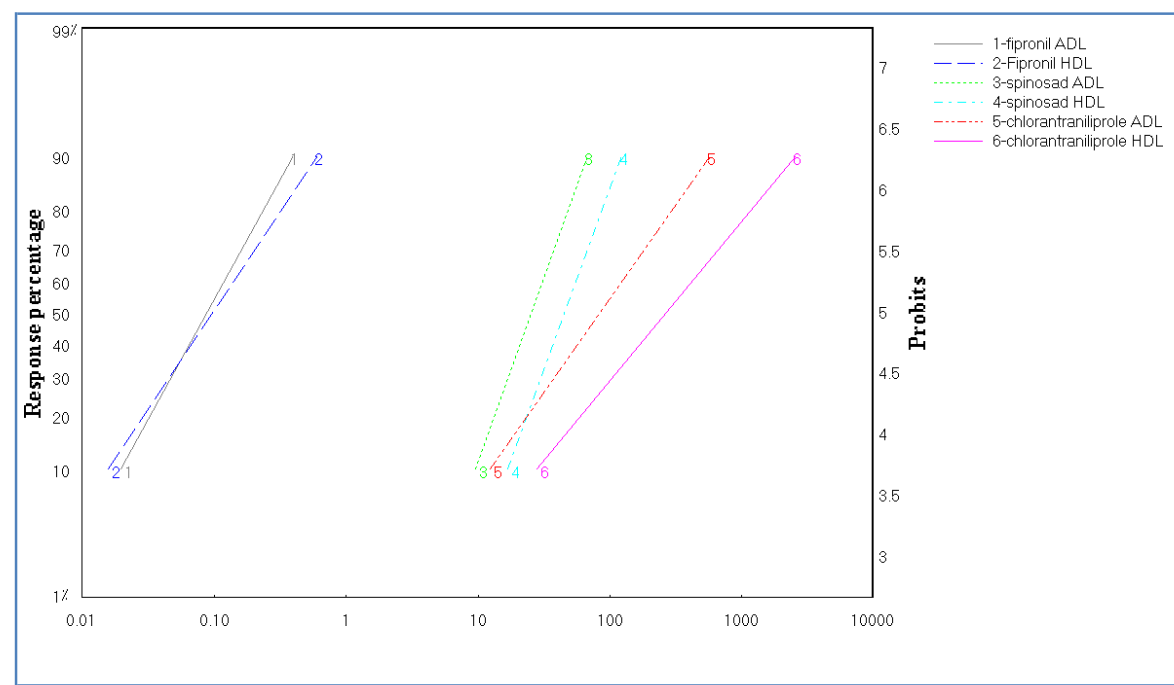

Figure 2: Toxicity lines of chlorantraniliprole, spinosad and fipronil on the $5^{\text {th }}$ nymphal instars and adults of $S$. gregaria (ADL= adults of desert locust and HDL= hoppers of desert locust).

These nymphs were weak, inactive and stayed alive for more than 30 days. The mentioned study also found that the doses of 50 and $40 \mu \mathrm{g} / 4^{\text {th }}$ instar nymphs resulted in 46.7 and $55.66 \%$ deformed $5^{\text {th }}$ instar nymphs which failed to shed their exuvia completely and died. Additionally; the same study found that a dose of $30 \mu \mathrm{g} / 4^{\text {th }}$ instar nymphs caused $50 \%$ of the resulting $5^{\text {th }}$ nymphal instar to fail from reaching the adult stage, due to inability to shed off their exuvia in spite of the occurrence of the adult cuticle.

Table 3. The effect of $\mathrm{LC}_{30}$ of chlorantraniliprole, spinosad and fipronil on some biological aspects of $S$. gregaria

\begin{tabular}{llll}
\hline \multicolumn{1}{c}{ Treatment } & \multicolumn{1}{c}{$\begin{array}{c}\text { Hopper } \\
\text { duration (days) }\end{array}$} & $\begin{array}{c}\text { Hopper } \\
\text { deformation \% }\end{array}$ & \multicolumn{1}{c}{$\begin{array}{c}\text { Adult } \\
\text { fledging \% }\end{array}$} \\
\hline Chlorantraniliprole & $12.6^{\mathrm{b}}$ & $0 \%^{\mathrm{a}}$ & $42.6^{\mathrm{c}}$ \\
Spinosad & $15.6^{\mathrm{c}}$ & $30 \%^{\mathrm{b}}$ & $75^{\mathrm{b}}$ \\
Fipronil & $11.6^{\mathrm{b}}$ & $30 \%^{\mathrm{b}}$ & $25^{\mathrm{d}}$ \\
Control & $8.8^{\mathrm{a}}$ & $0 \%^{\mathrm{a}}$ & $100^{\mathrm{a}}$ \\
LSD $(\mathbf{0 . 0 5 \% )}$ & 1.86 & 0.56 & 2.56 \\
\hline
\end{tabular}

Same letters are not significantly different

\section{Efficacy of chlorantraniliprole, spinosad}

and fipronil on the desert locust S. gregaria

\section{under field conditions}

The data in table 4 indicates the mortality rates caused by chlorantraniliprole, spinosad and fipronil under field conditions. No mortality was recorded in the control plot after 2 days of application among the mixed population of hoppers and adults. After 3, 6,
12, 24 and $48 \mathrm{hr}$. of treatment with $2 \mathrm{ml} / \mathrm{L}$ of chlorantraniliprole (24 g. a. i. /ha), the mortality percentages were $0 \% 12 \%, 40 \%$, $82 \%$ and $98 \%$ for mixed population of $3^{\text {rd }}$, $4^{\text {th }}, 5^{\text {th }}$ nymphal instars and immature adults of $S$. gregaria. The results agrees with those obtained under field conditions by Bradshaw et al., (2013) who found that chlorantraniliprole (Coragen ${ }^{\circledR}$ at dose rate of $2 \mathrm{oz} / \mathrm{A}$, and Prevathon ${ }^{\circledR}$ at dose rates of 7.8 oz/A and $13.6 \mathrm{oz} / \mathrm{A}$ ), as anthranilic diamide 
compounds, could reduce the populations of rangeland grasshoppers.

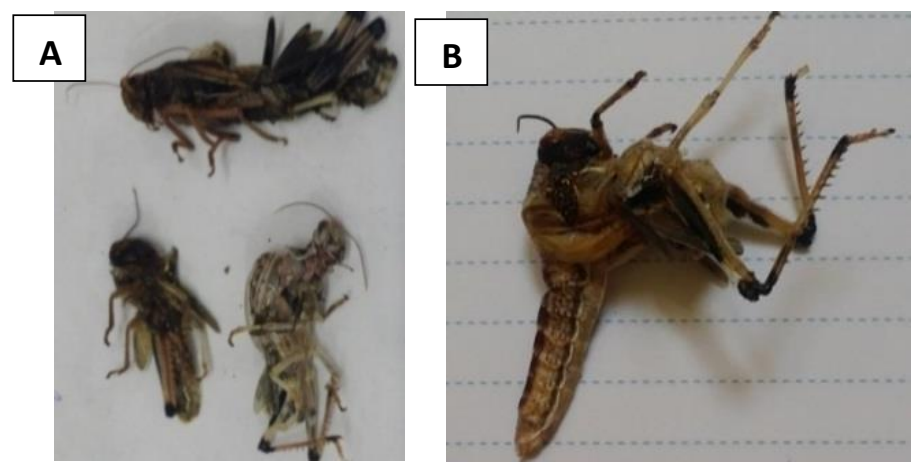

Figure 3. Malformed hoppers (a) and failure of moulting (b) caused by sub-lethal concentrations of spinosad $\left(\mathrm{LC}_{30}\right)$ in $S$. gregaria

The mortality percentages caused by $1 \mathrm{ml} / \mathrm{L}$ of spinosad (15.12 g. a. i./ha) after 3, 6, 12, 24 and $48 \mathrm{hr}$. of treatment were $2 \% 18 \%$, $69 \%, 92 \%$ and $99 \%$ for mixed population of $3^{\text {rd }}, 4^{\text {th }}, 5^{\text {th }}$ nymphal instars and immature adults of $S$. gregaria. The results agree with those found by Hosny et al., (2010) who indicated that spinosad at the concentration of $65 \mathrm{ml} / 100 \mathrm{~L}$ caused $75 \%$ and $100 \%$ mortality among $S$. gregaria nymphs after 24 and $48 \mathrm{hr}$. respectively. The study also found that spinosad caused 83.3 and $100 \%$ mortality after 24 and $48 \mathrm{hr}$. when applied against common grasshoppers at Baharia Oasis at concentration of $50 \mathrm{ml} / 100 \mathrm{~L}$. Additionally; in her MSc thesis, Kamel (2018) found that spinosad (Tracer®) caused high rate of mortality to the hoppers of $S$. gregaria after $48 \mathrm{hr}$. of field treatment.

The mortality percentages after $3,6,12,24$ and $48 \mathrm{hr}$. post treatment with $0.031 \mathrm{ml} / \mathrm{L}$ of fipronil (0.4 g. a. i./ha) were $20 \% 55 \%, 84 \%$, $96 \%$ and $100 \%$ for mixed population of $3^{\text {rd }}$, $4^{\text {th }}, 5^{\text {th }}$ nymphal instars and immature adults of $S$. gregaria. Similar results were found by Abdel-Fattah et al. (2012), when applying fipronil (Regent $\left.{ }^{\circledR}\right)$ in the field against the nymphal instars of $S$. gregaria and Euprepocnemis plorans plorans. As well, the finding also agrees with that by Abdel-Fattah and Ammar (2005) in the field against the $4^{\text {th }}$ and $5^{\text {th }}$ nymphal instars of $S$. gregaria. They found that fipronil (Reagent ${ }^{\circledR}$ ) could eliminate $92.8 \%$ of the hopper population within 2 days of treatment.

Table 4. Mortality percentages of $S$. gregaria caused under field conditions

\begin{tabular}{cccccc}
\hline $\begin{array}{c}\text { Time after } \\
\text { treatment (hr.) }\end{array}$ & chlorantraniliprole & spinosad & fipronil & Chloropyrifos & Control \\
\hline $\mathbf{3}$ & 0 & 2 & 20 & 74 & 0 \\
$\mathbf{6}$ & 12 & 18 & 55 & 90 & 0 \\
$\mathbf{1 2}$ & 40 & 69 & 84 & 100 & 0 \\
$\mathbf{2 4}$ & 82 & 92 & 96 & --- & 0 \\
$\mathbf{4 8}$ & 98 & 99 & 100 & --- & 0 \\
\hline
\end{tabular}




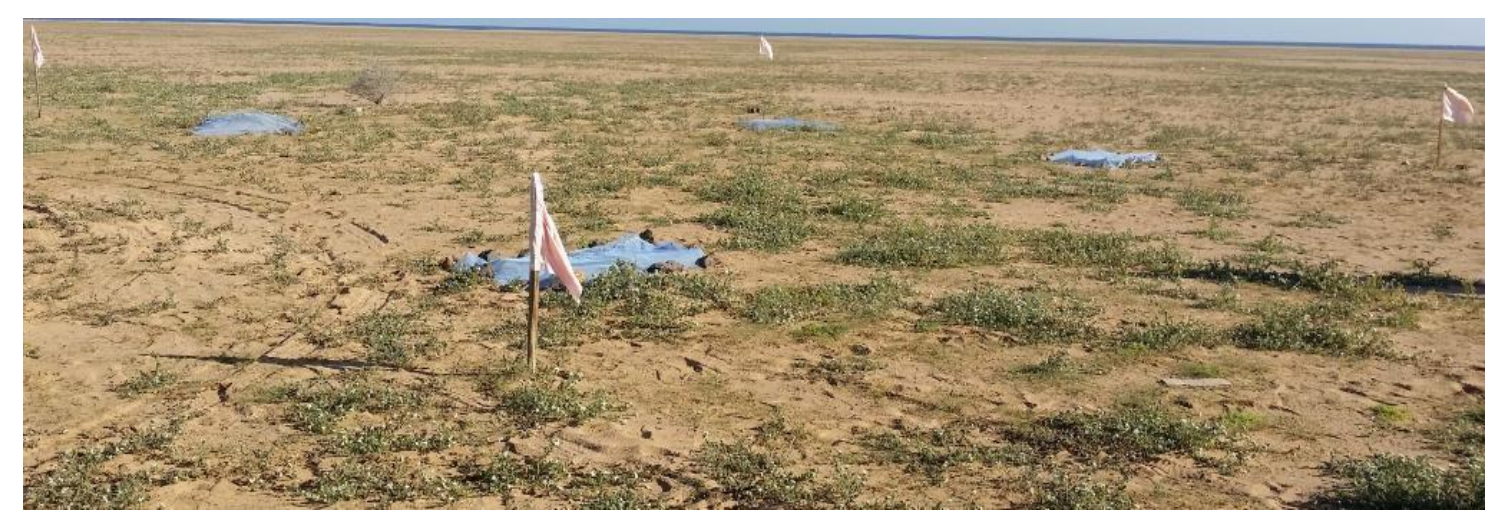

Figure 4. One of the plots at the site of treatment demarcated by flags
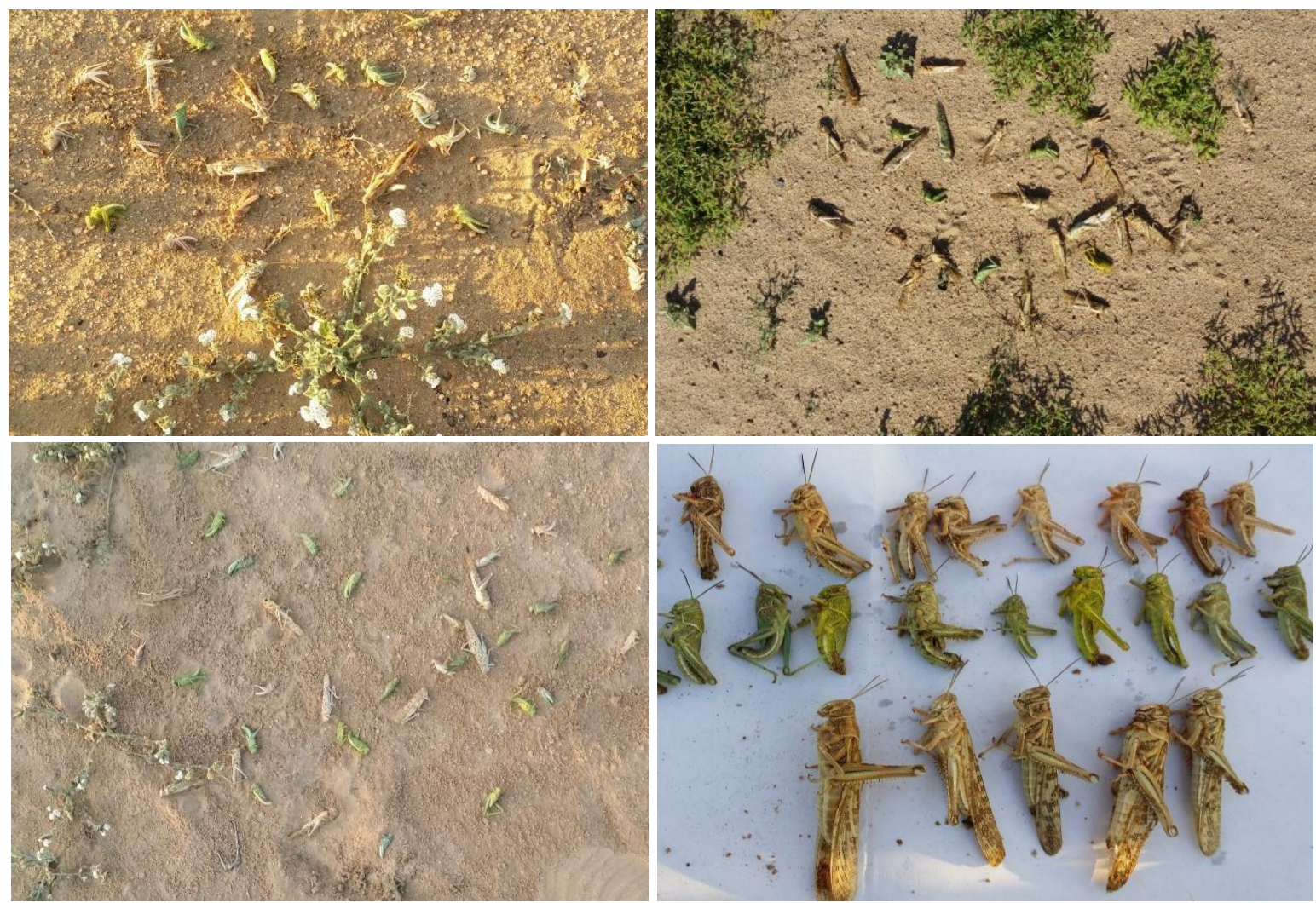

Figure 5. Images showing the dead adults and hopper in various instars after the field test

\section{In conclusion}

The present study aimed to find new alternatives to the conventional chemical insecticides against the desert locust $S$. gregaria, by testing the efficacy of chlorantraniliprole, spinosad and fipronil on the hopper and adult stages of $S$. gregaria. The results indicated that all the tested pesticides caused satisfactory mortality rates within one to three days of treatment against both stages under laboratory conditions.
Whereas; under field conditions, these products could reduce the locust stages in two days as well as the standard product Chlorzan ${ }^{\circledR} \quad$ (chloropyrifos) which could eliminate the infestation within $12 \mathrm{hr}$. The mentioned compounds also affected some biological aspects in the treated $5^{\text {th }}$ nymphal instar hoppers when used at sublethal concentrations including elongation of hopper duration, malformation and failure of ecdysis, and reduction in the fledging rates. 


\section{References}

Abbott W.S. (1925) 'A method for computing the effectiveness of an insecticide', J. Econ. Entomol., 18, 265 267.

Abdel-Fattah T.A. and Ammar A.E. (2005) 'Effect of different restrictors on the toxicity of some insecticides against the desert locust in Abo Ramad, eastern desert Egypt', Egyptian journal of agricultural research, 83 (2), 563-572.

Abdel-Fattah T.A., Gehan A.M. and AbdelLattef J.M. (2012) 'Effectiveness of some insecticides against the desert locust and berseem grasshopper in the field', Egyptian Journal of Applied Sciences, 27 (7), 89-96.

Bradshaw J., Jenkins K., Whipple S.D. and Patrick R. (2013) ' Evaluation of a new chemistry for Rangeland grasshopper control', Nebraska beef cattle reports, 721. pp. 45-48.

Cao G., Jia M., Zhao X., Wang L., Tu X., Wang G., Nong $X$. and Zhang $Z$. (2017) 'Effects of chlorantraniliprole on detoxification enzymes activities in Locusta migratoria L', Journal of AsiaPacific Entomology. 20, 741-746.

Cressman K. (2001) 'Desert locust guidelines 2: Organisation of the United Nations, Rome, 2nd edition', Survey', Food and Agriculture

El-Gammal A.M., Abdel-Fattah T.A., Mohamed M.T. and El-Gawhary H.M. (2004) 'The anti-juvenile hormone action of cycloheximide (RNA and protein synthesis inhibitor) in some nymphal instars of Schistocerca gregaria(Forskal)', Egyptian Journal of Agricultural Research, 82 (4), 15611571.

Finney D.J. (1971) 'Probit Analysis, third ed', Cambridge University Press, Cambridge.
Garriga M. and Caballero J. (2011) ' Insigths into the structure of urea-like compounds as inhibitors of the juvenile hormone epoxide hydrolase (JHEH) of the tobacco hornworm Manduca sexta: Analysis of the binding modes and structure-activity relationships of the inhibitors by docking and CoMFA calculations', Chemosphere, 82, 16041613.

Hosny A.K.H., Agamy E.A., Taha G.Z. and El- Husseini M.M. (2010) ' Influence of the Actinomycete Natural Metabolite "Spinosad" on certain locusts and grasshoppers (Orthoptera: Acrididae) in Egypt', Egyptian Journal of Biological Pest Control, 20 (2), 175-177.

Ibrahim M.R.A. (2018) ' Molecular impacts of some bio-isolates from Egypt on locust. MSc Thesis', Ain Shams University, Egypt.

Kamel R.W.M. (2018) 'The efficiency of some biological agents to the desert locust. MSc Thesis', Ain Shams University, Egypt.

Lecoq M.( 2001) ' Recent progress in Desert and Migratory Locust management in Africa. Are preventative actions possible?', Journal of Orthoptera Research, 10 (2), 277-291.

Pretty J.N.( 1996) ' Regenerating agriculture: policies for sustainability and selfreliance', Earth scans Publications Ltd., London, England, 320 pp.

Robert M.O., Andrena K., Goettel M.S., Jacques B. and Micheal J.B.( 2002) 'Attenuation of fungal infection in thermoregulating Locusta migratoria is accompanied by changes in haemolymph proteins', Journal of Invertebrate Pathology, 81, 19-24.

Said M.S. (2014) 'Effect of spinosad and consult on fifth nymphal instar of desert locust Schistocerca gregaria (Forskal). 
Soliman et al., : SVU-International Journal of Agricultural Sciences, 1 (1): 46-55, 2019

PhD Thesis', Cairo University, Egypt.

Tingle C.C.D. (1996) 'Sprayed barriers of diflubenzuron for control of the migratory locust (Locusta migratoria capito (Sauss.)) [Orthoptera: Acrididae] in Madagascar: Short-term impact on relative abundance of terrestrial nontarget invertebrates', Crop Protection, $15,579-592$. 